\title{
MODEL DEVELOPMENT OF POTENTIAL AREA SUITABILITY DETERMINATION OF SKIPJACK TUNA CATCH USING MULTI SENSOR SATELLITE AND GEOGRAPHIC INFORMATION SYSTEM IN WEST PAPUA WATERS
}

\author{
Tjarles Lay \\ Master's Degree Program in Marine Sciences, University of Pattimura, Indonesia \\ Matruty D.D.P. \\ Department of Fisheries Resources Utilization, Faculty of Fisheries and Marine Sciences, \\ University of Pattimura, Indonesia \\ Waas H.J.D. \\ Department of Marine Sciences, Faculty of Fisheries and Marine Sciences, \\ University of Pattimura, Indonesia \\ *E-mail: laytjarles@gmail.com
}

\begin{abstract}
A study of the model development of potential area suitability determination of skipjack tuna (Katsuwonus pelamis) catch using multiple satellite sensors and GIS (Geographic Information Systems) in West Papua waters was carried out during January - June 2019. This study aimed to develop a model of potential area suitability determination of skipjack tuna catch in West Papua waters. This study was exploratory research by compiling data of pole and line skipjack catch, multi-sensor satellite imagery data, and analysis of the determination of suitability areas using GIS. The results found three main parameters: Sea Surface Temperature (SST), Chlorophyll-a, and Batimetri waters in forming a catchment suitability area in West Papua waters. There were two categories found during the west monsoon and transitional seasons I (unsuitable and less suitable). Unsuitable categories at position $0^{\circ} 30 " \mathrm{NL}-2^{\circ} 20^{\prime \prime} \mathrm{SL} ; 129^{\circ} 10^{\prime \prime}-131^{\circ} 00 \mathrm{EL}$ include the eastern part of Misool Island, Kafiau Island, Gag Island and Waigeo Island. The east monsoon of the skipjack catch potential had two categories (less suitable and suitable). The suitable category tends to be found at the westward at the position of $0^{\circ} 20^{\prime \prime N L}-03^{\circ} 10^{\prime \prime S L} ; 127^{\circ} 00^{\prime \prime}-131^{\circ} 00^{\prime \prime} \mathrm{EL}$, including Halmahera Sea and part of Seram Sea. Seasonal Transition II is the best place for catching skipjack tuna. Based on the prediction mapping results, the potential areas are categorized as less suitable and suitable. The suitable categories found throughout the area of study: Fakfak waters, Seram Sea, Halmahera Sea, Manokwari waters, and southern Maluku islands.
\end{abstract}

\section{KEY WORDS}

Sea surface temperature, chlorophyll-a, bathymetry, catching area, skipjack tuna.

West Papua waters, part of eastern Indonesia waters, have promising marine biodiversity potential, among others, large pelagic fish such as skipjack tuna.The number of the potential of skipjack tuna resources in West Papua in 2017 was estimated at 16,203.58 tons or $7.57 \%$ of the total production of skipjack tuna fisheries in Indonesia (KPDA KKP, 2018). Skipjack tuna catch in West Papua waters is still done by huntin, following natural signs such as the hordes of dolphins and whales, hordes of birds and floating objects such as branches and tree trunks, logs, and the use of FADs to collect fish (Waas, 2004).

To increase the production of skipjack tuna catc in West Papua waters, we need technology to determine potential capture areas so that the fleet will be easily directed to the fishing ground to save time, cost, and fuel. Remote sensing multi-sensor satellite is one of the technologies that have been utilized by tuna and skipjack tuna industrial countries because of the high frequency of observation and lower operational costs when compared to 
other methods (Robinson, 1985). Information on environmental/ecological indicators can help estimate the location, distribution, and behavior of fish (Chen et al, 2005). Based on the description above, this study aimed to develop a model of potential area suitability determination of skipjack tuna catch in West Papua waters.

\section{METHODS OF RESEARCH}

This research was conducted during January - June 2019 in Sorong Coastal Fisheries Port, which is a fishing base. Skipjack tuna catch as the research data were done using pole and line and fishing ground in Missol island waters (Seram Sea), Waigeo Island (Halmahera Sea), and Fakfak waters. While the data of the sea surface temperature, chlorophyll-a, geostrophic currents, wind, waves, and sea depth are collected during January - December 2018. Geographically, the location of the study is limited to coordinates $0^{\circ} 30^{\prime} 00^{\prime \prime} \mathrm{NL}-4^{\circ} 30^{\prime} 00^{\prime \prime}$ SL and $127^{\circ} 00^{\prime} 00$ "- $135^{\circ} 00^{\prime} 00^{\prime \prime} \mathrm{EL}$.

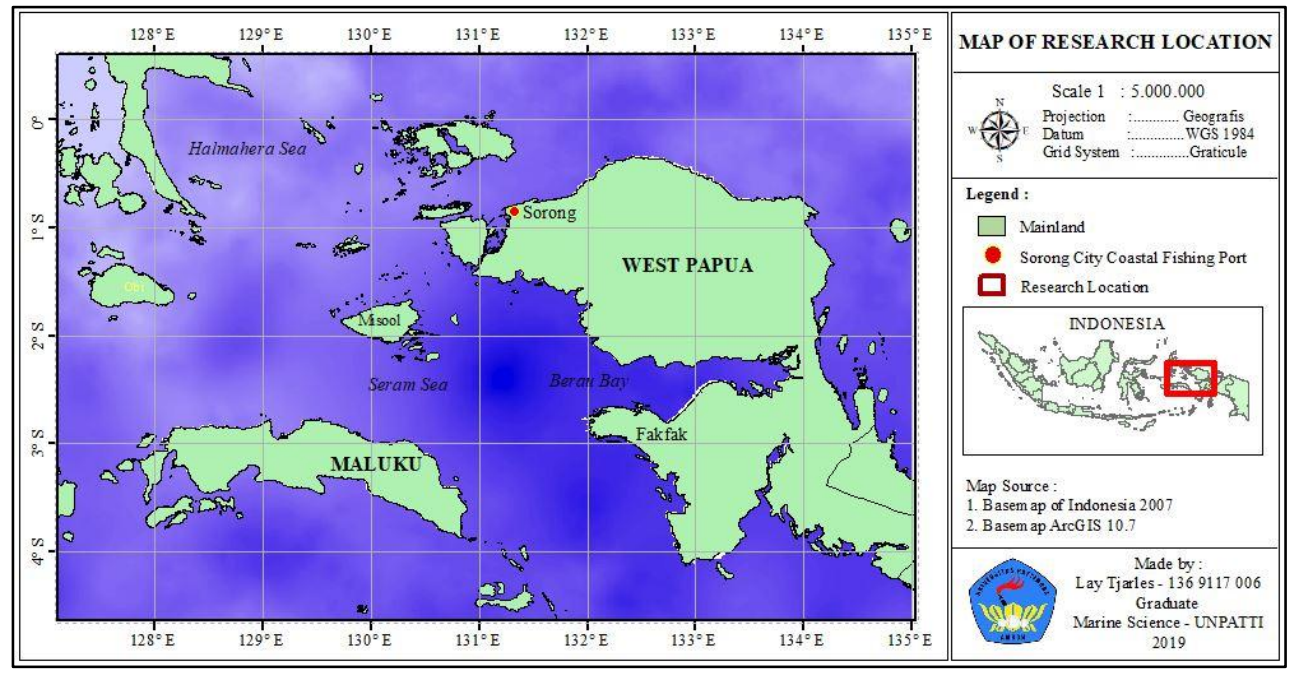

Figure 1 - Map of Reserach Location

Tools and materials:

(1) Oceanographic parameters in 2018 included:

- Sea Surface Temperature Image, Multi-scale Ultra-high Resolution (MUR) resolution $0.01^{\circ}$;

- Image of chlorophyll-a concentration Aqua Modis with $0.025^{\circ}$ resolution;

- Geostrophic current image, a combination of Topex/Poisedon and ERS satellites;

- ASCAT satellite wind speed image with a resolution of $0.25^{\circ}$;

- Depth of GEBCO (General Bathymeric chart of the oceans).

(2) Data of fishing ground location and skipjack tuna catch from pole and line fleet in 2018 were obtained from the fishing logbook information system or Sistem logbook penangkapan ikan (SILOPI) of the Ministry of Maritime Affairs and Fisheries at Sorong Coastal Fisheries Port and PTCanning Citra Raja Ampat;

(3) Software ArcGIS 10.7;

(4) Software Surfer 16;

(5) Software Snipping Tool;

(6) Laptop Intel Core i5 RAM 4 GB.

This study was an exploratory research aimed to broadly explore the causes or things that influence the occurrence of something, to develop a tentative theory and model, and to open up the possibility of further research on the topics discussed.

In situ data collection of oceanographic physical conditions such as temperature, chlorophyll-a, wind, geostrophic flow velocity, and depth of water is done online.While sampling of other oceanographic physical and biological data is carried out through the 
results of synoptic weeding of oceanographic satellites. Skipjack tuna catch data is focused on the capture logbook of 26 pole and line vessels with a capacity of 55 - 97 GT (Gross Ton) including vessel data, capture position, and the number of catches each trip (trip based on houling). Determination of fishing season depends on the results of interviews with the skipper and shipowner.

Model development of potential fishing area suitability determination is carried out using oceanographic multi-sensor satellite imagery data.This is based on the relationship between water surface conditions and the processes in the water column, meaning that the oceanographic processes in the water column can be detected through the water surface conditions. Determination of potential fishing areas is made based on the results of overlay characterized by the condition of SST, chlorophyll-a, and certain water depths without the presence of oceanographic features. Potential areas are divided into three categories: category 1 or non-potential areas (not suitable), category 2 or less potential area (less suitable), and category 3 or high potential area (suitable). Creteria is arranged based on the data of skipjack tuna catch in 2018 using pole and line. The analysis was performed using a geographic information system. Determination of potential area criteria is the result of modification of water suitability parameters for capture fisheries issued by the Directorate of sea spatial planning, the Ministry of Maritime Affairs and Fisheries in 2016.

\section{RESULTS AND DISCUSSION}

The results of the analysis showed that during 2018, the highest SST was in January by $30.67{ }^{\circ} \mathrm{C}$ with average SST of $30.15^{\circ} \mathrm{C}$ and the lowest in July by $25.69^{\circ} \mathrm{C}$ with average SST of $28.48^{\circ} \mathrm{C}$ (Figure 2 ).

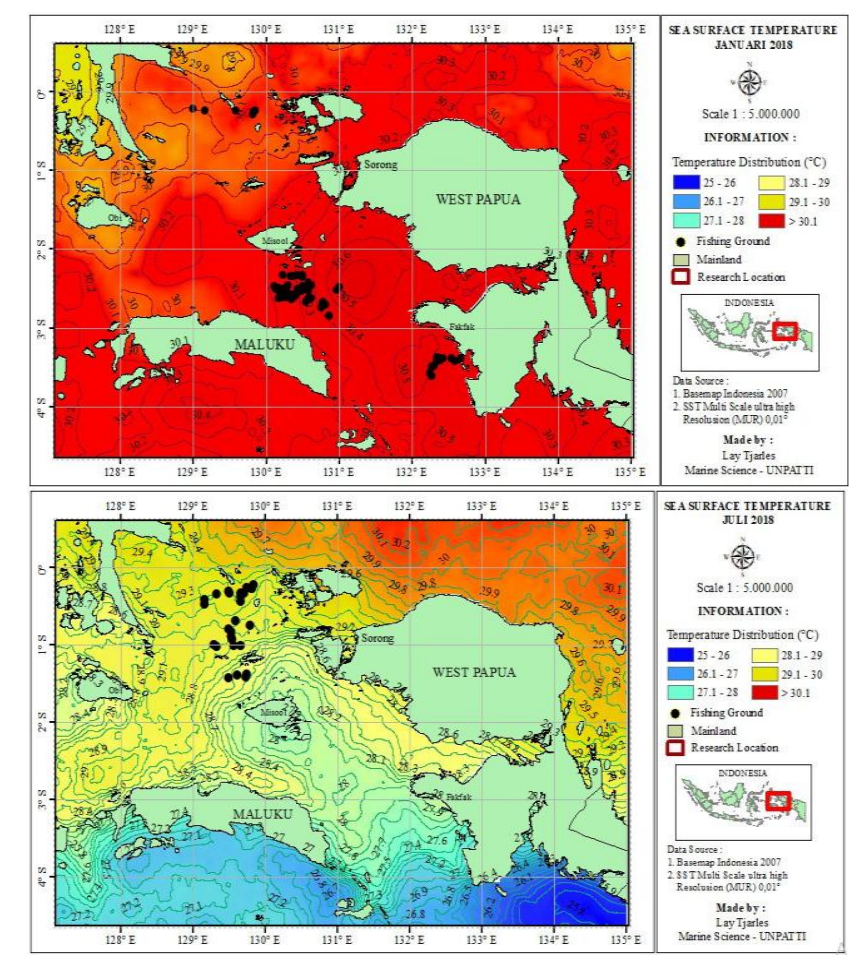

Figure 2 - SST concentration in January and July 2018

Changes in monthly SST also influenced the dynamics of seasonal SST. Table 1 shows the SST seasonal profile.

West monsoon SST concentrations higher than $30^{\circ} \mathrm{C}$ occurred in January, covering almost all West Papua and Maluku waters. However, in February, March, and December of 
the next period, the conditions of SST were relatively lower than $29.73{ }^{\circ} \mathrm{C}$. The eastern part of Seram sea, Berau bay, and Fakfak waters had an average SST above $30^{\circ} \mathrm{C}$.

SST average value of west monsoon and transitional season I did not differ much. The SST of the transitional season I only decreased the temperature by $0.08{ }^{\circ} \mathrm{C}$. Transitional season image I shows that high temperatures $>30^{\circ} \mathrm{C}$ occurred in two areas: the northern part of west Seram in between the islands of Obi and Missol and the northeastern part of Seram sea up to the southern part of Papua island (Figure 3).

Table 1 - Seasonal SST Profile in West Papua waters and the surroundings

\begin{tabular}{|c|c|c|c|c|}
\hline \multirow{2}{*}{ SEASON } & \multicolumn{4}{|c|}{ Sea Surface Temperature $\left({ }^{\circ} \mathrm{C}\right)$} \\
\cline { 2 - 5 } & Min & Max & Mean & STD \\
\hline WEST MONSOON & 29.34 & 30.24 & 29.81 & 0.15 \\
\hline TRANSITION 1 & 29.02 & 30.50 & 29.73 & 0.30 \\
\hline EAST MONSOON & 26.20 & 30.13 & 28.54 & 0.99 \\
\hline TRANSITION II & 28.47 & 30.08 & 29.37 & 0.29 \\
\hline
\end{tabular}

A real change occurred during the east monsoon (June - September). Sea surface temperature ranged from $26.20-30.13^{\circ} \mathrm{C}$ with an average temperature of $28.54^{\circ} \mathrm{C}$. The analysis showed the decrease in minimum temperature by $2.82^{\circ} \mathrm{C}$ and the maximum temperature by 0.37 from the transition season I. The lowest temperature of $26.20^{\circ} \mathrm{C}$ occurred in Kaimana waters, Fakfak watersm, and the southern part of Maluku siland where the temperatures ranged between $27-28^{\circ} \mathrm{C}$. The SST of Seram Sea, Berau bay, and western part of Raja Ampat Islands ranged between $28-29^{\circ} \mathrm{C}$. While Halmahera, Waigeo islands, and northern part of West Papua's SST was above $29^{\circ} \mathrm{C}$.

The east monsoon showed that cold temperatures were dominant in the south to the eastern part of West Papua and Maluku waters. The analysis results of east monsoon (June September) showed that there was a movement of cold temperatures drifting from the bottom (southeast) and then rose up to pass the Kei Islands to Fakfak waters and the Seram Sea.

During the transitional season II (October - November), the sea surface temperature had increased from 28.47 to $30.08^{\circ} \mathrm{C}$ with an average of $29.37^{\circ} \mathrm{C}$. The results of the analysis showed a minimum temperature increase of $2.27{ }^{\circ} \mathrm{C}$. It indicated that the maximum temperature did not increase from the previous season period. The average SST rose $0.83^{\circ} \mathrm{C}$ from the east monsoon. Distribution of transitional season II SST is distributed throughout West Papua waters and its surroundings.

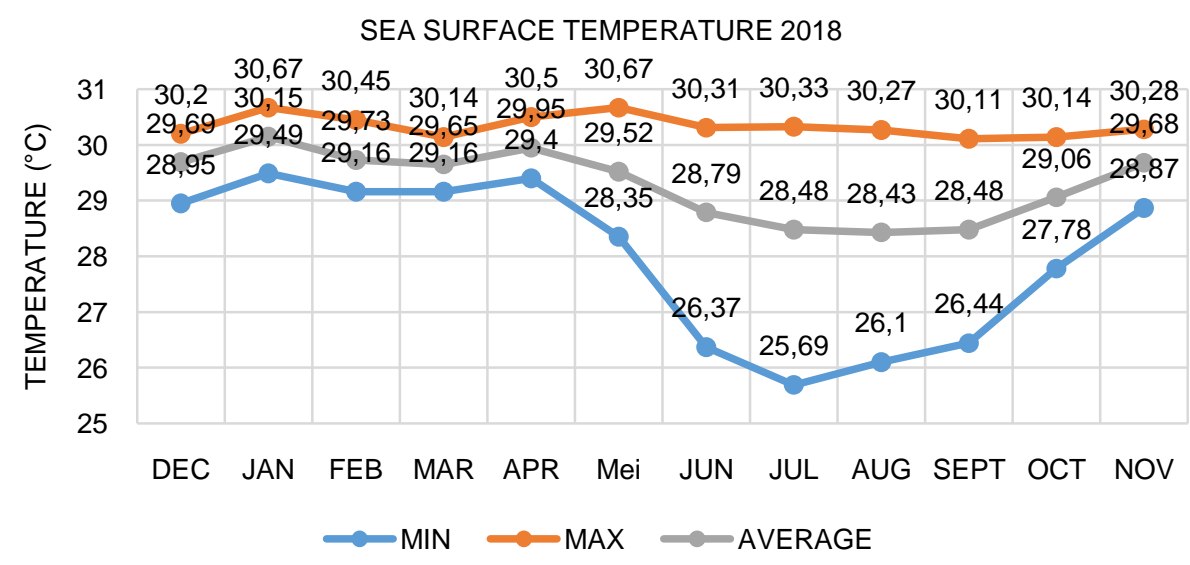

Figure 3 - SST fluctuations in West Papua waters and the surrounding areas in January to December of 2018

The monthly average of the distribution of chlorophyll-a concentrations in West Papua waters and the surrounding areas showed that chlorophyll-a concentrations ranged from 
$0.309-0.579 \mathrm{mg} / \mathrm{m}^{3}$ higher in the east monsoon and lower in the west monsoon. Temporally, the high peak chlorophyll-a concentration starts from May to August with the highest peak in June (Figure 4).

Table 2 - Average Chlorophyll-a Concentration by Season

\begin{tabular}{|c|c|c|c|c|}
\hline \multirow{2}{*}{ SEASON } & \multicolumn{4}{|c|}{ Chlorophyll-a concentration $(\mathrm{mg} / \mathrm{m} 3)$} \\
\cline { 2 - 5 } & Min & Max & Mean & STD \\
\hline WEST & 0.077 & 44.846 & 0.304 & 0.85 \\
\hline TRANSITION 1 & 0.071 & 166.184 & 0.446 & 2.00 \\
\hline EAST & 0.071 & 69.412 & 0.480 & 1.07 \\
\hline TRANSITION II & 0.053 & 106.40 & 0.358 & 1.09 \\
\hline
\end{tabular}

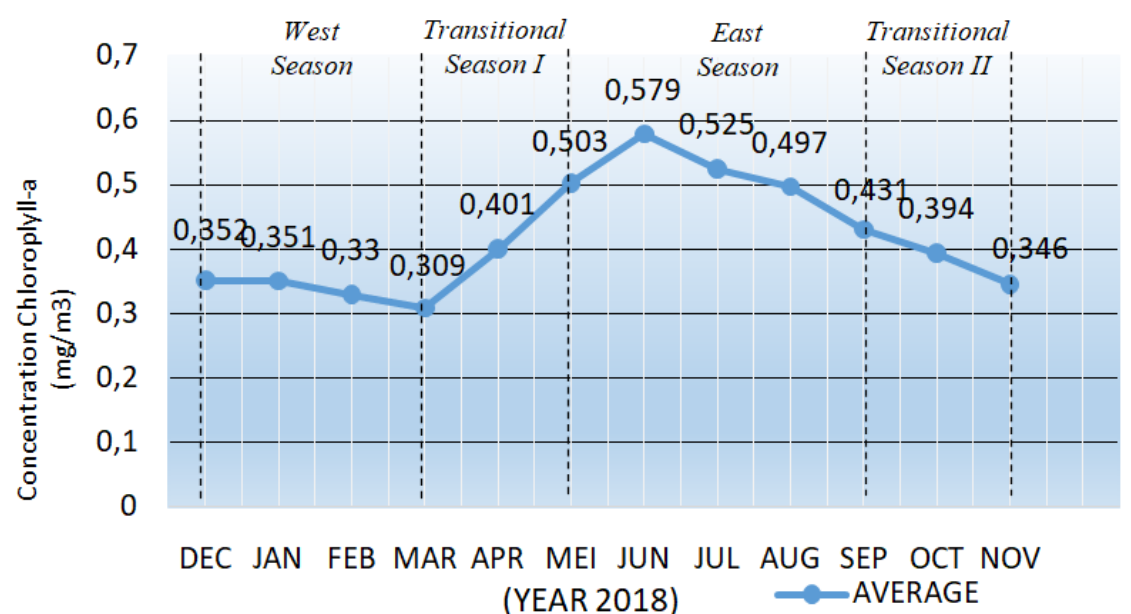

Figure 4 - Fluctuations of average chlorophyll-a concentration between January-December 2018 in West Papua Waters

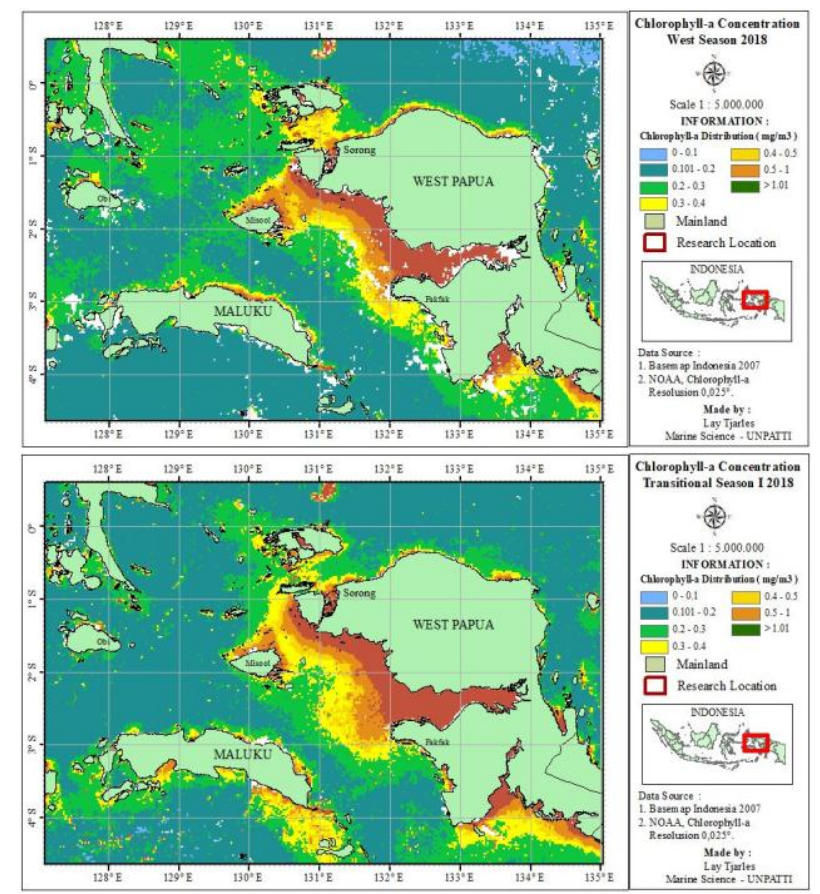

Figure 5 - Chlorophyll-a Concentration of West Monsoon and Transition I

The average chlorophyll-a concentration of the west monsoon (December - March) was $0.304 \mathrm{mg} / \mathrm{m}^{3}$. The highest average chlorophyll-a concentration was in December by 0.352 $\mathrm{mg} / \mathrm{m}^{3}$ while the lowest in March by $0.309 \mathrm{mg} / \mathrm{m}^{3}$. The average chlorophyll-a concentration of 
the transitional season I (April - May) was $0.446 \mathrm{mg} / \mathrm{m}^{3}$. The highest average was in May by $0.503 \mathrm{mg} / \mathrm{m}^{3}$ and the lowest in April by $0.401 \mathrm{mg} / \mathrm{m}^{3}$. The average chlorophyll-a concentration of transitional season I increased $0.142 \mathrm{mg} / \mathrm{m}^{3}$ from the west monsoon (Figures 4 and 5). The average chlorophyll-a concentration of east monsoon (June September) was $0.483 \mathrm{mg} / \mathrm{m}^{3}$. The highest average was in June by $0.579 \mathrm{mg} / \mathrm{m}^{3}$ and the lowest in September by $0.431 \mathrm{mg} / \mathrm{m} 3$. The east monsoon was the peak of high concentrations of chlorophyll-a which covers all West Papua, Maluku, and North Maluku waters. In transitional season II (October - November), the highest average chlorophyll-a concentration was 0.394 in October, and the lowest was $0.346 \mathrm{mg} / \mathrm{m}^{3}$ in November.

Image data in West Papua waters and its surroundings showed that chlorophyll-a concentrations were categorized high throughout the season with a range between 0.304 $.480 \mathrm{mg} / \mathrm{m}^{3}$.

The average chlorophyll-a concentration was generally low during the west monsoon and transitional seasons II. The average concentration of chlorophyll-a increased $>0.40$ $\mathrm{mg} / \mathrm{m}^{3}$ from April (transitional season I) to September with the highest peak in June by 0.579 $\mathrm{mg} / \mathrm{m}^{3}$ (east monsoon) and decreased again in October (Figures 4 and 6).

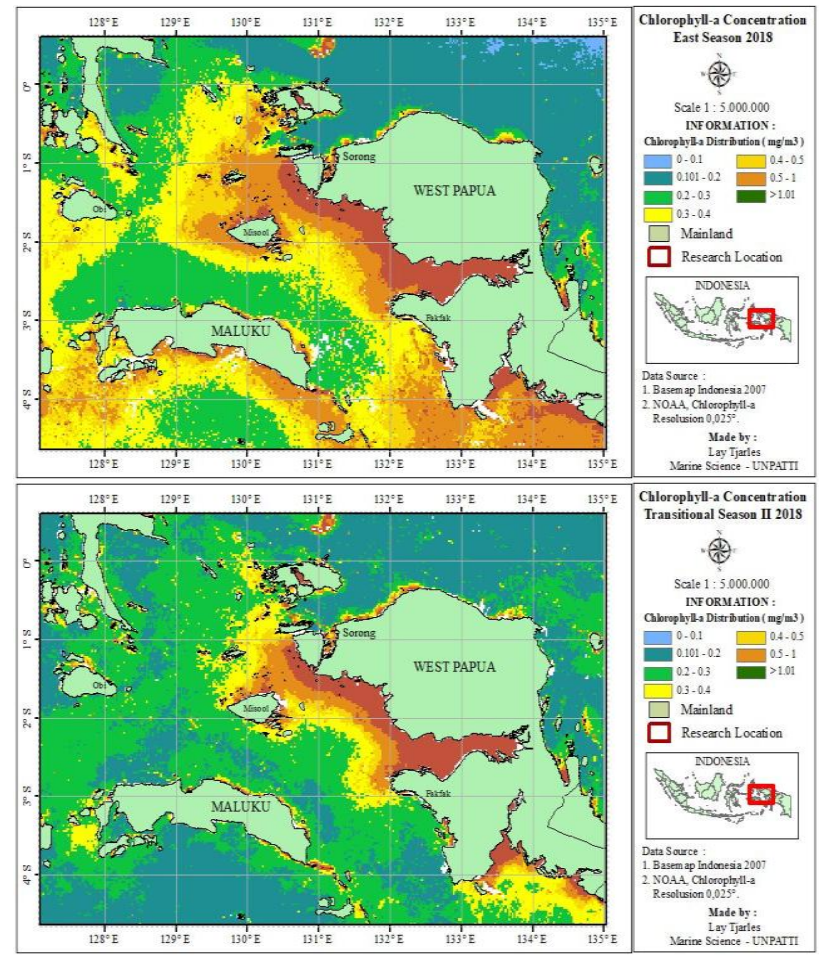

Figure 6 - Chlorophy Concentration of East Monsoon and Transition II

The data showed that the movement of ocean currents in West Papua waters and its surroundings in 2018 had a different speed and direction each month.

Table 3 - Average current speed based on the season in West Papua waters and surrounding areas

\begin{tabular}{|c|c|c|c|c|}
\hline \multirow{2}{*}{ SEASON } & \multicolumn{4}{|c|}{ Current Speed $(\mathrm{m} / \mathrm{s})$} \\
\cline { 2 - 5 } & Min & Max & Mean & STD \\
\hline WEST MONSOON & 0.037 & 1.107 & 0.308 & 0.156 \\
\hline TRANSITION 1 & 0.025 & 1.114 & 0.253 & 0.129 \\
\hline EAST MONSOON & 0.043 & 0.950 & 0.271 & 0.123 \\
\hline TRANSITION II & 0.026 & 1.552 & 0.301 & 0.188 \\
\hline
\end{tabular}

In the west monsoon, the current velocity ranged from $0.037-1.107 \mathrm{~m} / \mathrm{s}$ with an average current speed of $0.308 \mathrm{~m} / \mathrm{s}$. The fastest current speed was there around Adi islands in March, reaching up to $1.929 \mathrm{~m} / \mathrm{s}$. In general, during the west monsoon, there are 2 
directions of currents in West Papua waters and its surroundings: a movement from the bottom (southeast to northwest) and from upper (north to south). This confluence brings eddies around the eastern part of Seram Sea and moves east into the Berau bay.

The currents in the ocean are caused by internal and external factors. The internal factors include differences in seawater density, horizontal pressure gradients, and water layer friction. While the external factors include the tensile force of the sun and the moon influenced by the resistance of the seabed and the Coriolis force, the difference in air pressure, gravity, tectonic, and wind forces (Gross, 1990).

In the transitional season I (April - May), the average current speed was $0.253 \mathrm{~m} / \mathrm{s}$ and the speed and direction of the current was different. In April, the current velocity in Missol Island reached up to $1.97 \mathrm{~m} / \mathrm{s}$ with an average of $0.26 \mathrm{~m} / \mathrm{s}$. The current direction above Missol Island tends to move northwest to Seram Sea. While the current direction from Berau bay goes out westward then down south and forms an anti-cyclonic circulation pattern around Fakfak waters. In May, the current velocity decreased up to $1.35 \mathrm{~m} / \mathrm{s}$ with an average of $0.23 \mathrm{~m} / \mathrm{s}$. It was mostly happened in the Maluku sea (northern part of Maluku) with the current direction to the north.

Nontji (1993) stated that during the west-east transitional season, the flow to the east is starting to weaken and even begin to reverse until causing eddies in some places. Birowo (1980) also proposed that during the transitional season, the flow is volatile and difficult to determine.

The average current velocity of the east monsoon was $0.271 \mathrm{~m} / \mathrm{s}$. The highest speed was in July, reaching up to $2.46 \mathrm{~m} / \mathrm{s}$ with an average month of $0.29 \mathrm{~m} / \mathrm{s}$. In August and September, the current velocity decreased again. The lowest average speed was $0.25 \mathrm{~m} / \mathrm{s}$ in September. The direction of the currents movement tends to move north. This was influenced by the east monsoon and the SST in the southern part of West Papua, which is relatively lower so that the current movement from Banda Sea got into the eastern part of Seram Island to the north. However, in September, the direction of the current speed form Raja Ampat Island tended to move south and turned east through Seram Sea and met the current heading to the Berau gulf.

The current velocity of transitional season II (October - November) ranged from 0.026 $1.552 \mathrm{~m} / \mathrm{s}$ with an average of $0.301 \mathrm{~m} / \mathrm{s}$. In October, the current velocity in Missol Island and the northern part of Seram sea reached up to $1.42 \mathrm{~m} / \mathrm{s}$ with an average of $0.27 \mathrm{~m} / \mathrm{s}$. While in November, the highest current speed in Berau and Kamrau bay reached up to $2.59 \mathrm{~m} / \mathrm{s}$ with an average of $0.32 \mathrm{~m} / \mathrm{s}$ (see table 3 ).

The results of the analysis showed that seasonal wind speeds ranged from 4.07 28.39 knots with average wind speeds between 15.21 - 15.48 knots (Table 5)

The wind direction of the next season's west monsoon tends to move southeast with a velocity range of 5.17 - 25.96 knots and an average of 15.48 knots. Whereas at the transition $\mathrm{I}$, the wind blew from the southeast to the northeast with a speed range of $4.07-28.39$ knots with an average of 15.21 knots. During the east monsoon, the wind tended to blow to the northeast with a range of $5.37-27.3$ and an average of 15.25 knots. Based on the results of the monthly analysis of Seram Sea, the wind speed tended to be higher than in other regions. The direction of the wind during the transition II in October was still going northeast and changed to the southeast in November with a speed range of $5.33-27.66$ knots and an average of 15.32 knots.

Table 4 - Seasonal wind speed in the waters of West Papua and the surrounding areas

\begin{tabular}{|c|c|c|c|c|}
\hline SEASON & MIN & MAX & MEAN & STD \\
\hline WEST & 5.17 & 25.96 & 15.48 & 3.71 \\
\hline TRANSITION 1 & 4.07 & 28.39 & 15.21 & 3.98 \\
\hline EAST & 5.37 & 27.3 & 15.25 & 4.05 \\
\hline TRANSITION II & 5.33 & 27.66 & 15.32 & 4.09 \\
\hline
\end{tabular}

The analysis showed that the wave heights in West Papua waters and surrounding areas in 2018 varied between $0.04-2.28 \mathrm{~m}$ (Figure 7). Wave characteristics are influenced 
by wind speed, the faster the wind speed, and the higher the waves will be. Also, the waves are affected by depth differences, the shallower the waters, the quicker the waves will break (Hasriyanti et al, 2015). In the west monsoon, the wave height ranged from $0.06-1.37 \mathrm{~m}$, evenly throughout West Papuawaters and its surroundings. In January, it ranged from $0.05-$ $1.46 \mathrm{~m}$, but the height of the wave dominantly ranged between $0.5-1 \mathrm{~m}$. In February, the wave height in the western part of Seram sea and Raja Ampat islands ranges from 0.06 1.25. While in the Berau bay to Fakfak waters, the wave height tended to be under $0.5 \mathrm{~m}$. In contrast to the previous month, the wave heights in March increased between $0.06-1.52 \mathrm{~m}$, predominantly occurring in the eastern waters of West Papua $\left(132^{\circ}-135^{\circ} \mathrm{WL}\right)$. In the west monsoon of the next period, the wave height does not differ much; it still ranged between $0.09-1.10 \mathrm{~m}$ but dominantly between $0.5-1 \mathrm{~m}$ throughout West Papua waters.

The average height during the transitional season I ranged from 0.06 to $1.32 \mathrm{~m}$. In April, it ranged from 0.04 to $1.09 \mathrm{~m}$, decreasing $0.43 \mathrm{~m}$ from the west monsoon in March. The depth of the northern part of West Papua waters tended to be deeper than Seram sea and the southern part of Maluku whose the wave height is relatively small under $0.5 \mathrm{~m}$. In May, the wave height rose between $0.08-1.55 \mathrm{~m}$. In the position of $3^{\circ}-4.30^{\circ} \mathrm{SL}$, the dominant wave height is between $1-1.5 \mathrm{~m}$.

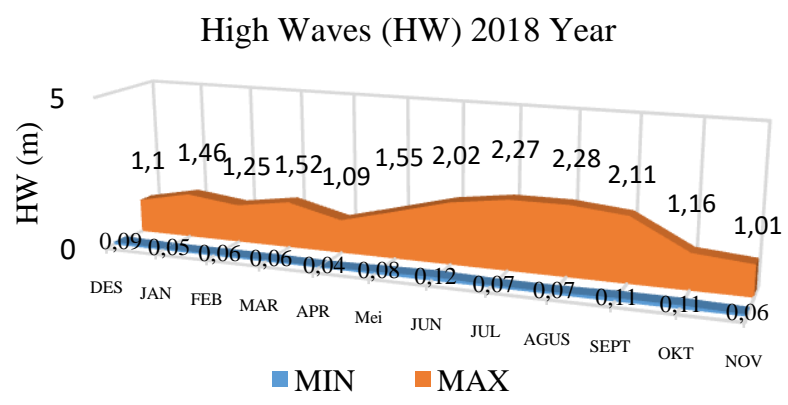

Figure 7 - Graph of average monthly wave height in 2018 in West Papua waters and the surrounding areas

The east monsoon is the peak of high waves in West Papua waters and its surroundings with an average range from 0.09 to $2.17 \mathrm{~m}$. The wave height in June, July, August, and September is $0.12-2.02 \mathrm{~m}, 0.07-2,27,0.07-2.28 \mathrm{~m}$, and $2.11 \mathrm{~m}$, respectively. The wave height in West Papua waters and its surrounding areas during the transitional season II was relatively decreased, between $0.07-1.05 \mathrm{~m}$, while in October and November, it ranged from $0.11-1.16 \mathrm{~m}$ and $0.06-1.01$, respectively.

The depth of West Papua waters and its surroundings area is different.The northern part of West Papua waters tends to be deeper than that of the southern part. It is directly adjacent to the Pacific sea whose depth> 2500 meters, while the depth of the western and southern part of West Papua waters is $<2000$ meters.

Vertical spread (depth strata) of skipjack tuna started from the surface to a depth of $260 \mathrm{~m}$ during the day and tended to go to the surface at night (Munirah, 2018). Opportunities of skipjack tuna catch at a depth of 51-100 m are higher compared to a depth of $>100 \mathrm{~m}$ (Munirah et al, 2015).

Depth analysis of West Papua waters, which is a skipjack fishing area, displays a different depth profile (see figure 8). Profile A of Seram Sea (Missol Island to Seram Island/Maluku) showed the extending sea trench form a channel/pool with a depth up to 2000 meters. The movement to the west will deepen the channel/pool up to 2500 meters. Fakfak Waters (Fakfak to Seram Island/eastern Maluku) show fluctuation dept reaching 1980 meters, getting closer to shallow waters of Seram Island. The sea trough (Seram Sea) connects Fakfak waters and Banda Sea. Halmahera Sea (Waigeo Island - South Halmahera) shows that the closer the distance to southern Halmahera, the much more sea through with a depth of up to 2600 meters. 

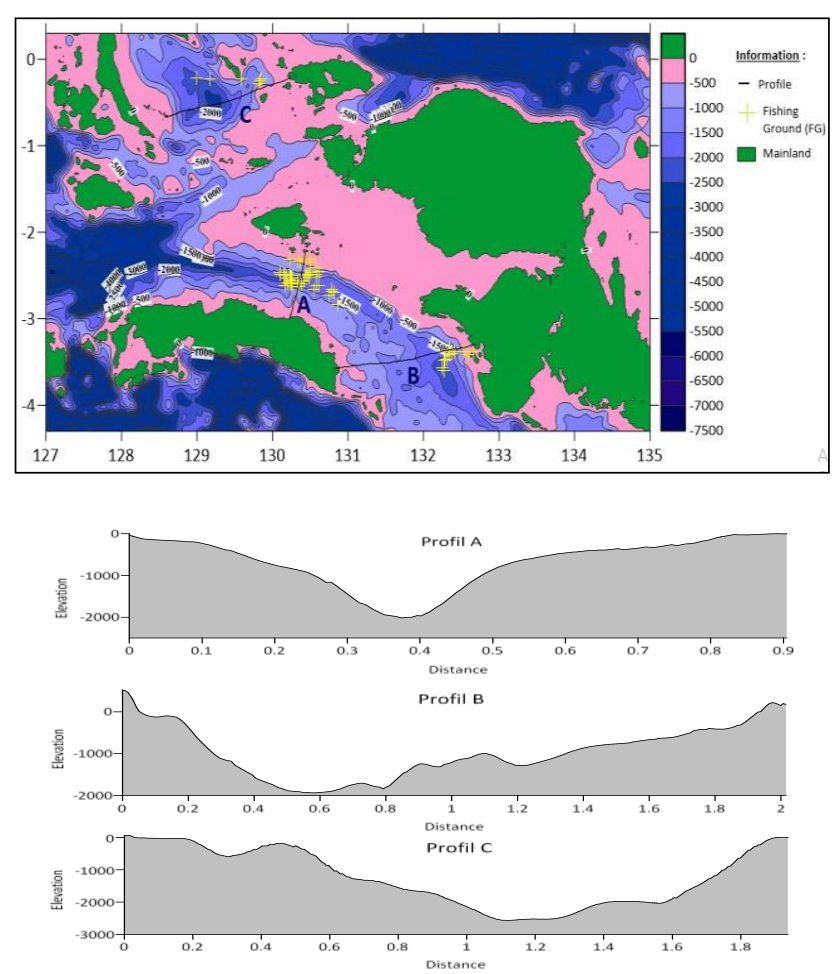

Figure 8 - Waters dept profile of A Seram Sea (Missol I. - Seram I.), B Fakfak Waters (Fakfak eastern part of Seram Sea), C Halmahera Sea (Waigeo I. - South Halmahera)

Based on the research data, the catch of skipjack tuna during 2018 reached up to $1,818.30$ tons. The number of pole and line vessels operating was 26 ships with a total fishing operation of 937 trips (total trip is calculated based on the time of capture at a certain place) so that the 2018 catch per unit (CPUE) was 1,941 tons/trip.

Most skipjack catch during the west monsoon was in March with an average of 2577 $\mathrm{kg} /$ trip. Its SST range was $29.45-29.83^{\circ} \mathrm{C}$ with an average of $29.66^{\circ} \mathrm{C}$. Chlorophyll-a ranged from 0.12 to $0.32 \mathrm{mg} / \mathrm{m}^{3}$ with an average of $0.18 \mathrm{mg} / \mathrm{m}^{3}$. Current speeds ranged from 0.03 to $0.50 \mathrm{~m} / \mathrm{s}$ with an average of $0.18 \mathrm{~m} / \mathrm{s}$. Wind speed ranged from $10.13-12.68$ knots with an average of 11.03 knots. Sea waves ranged from 0.59 to 1.03 meters with an average of 0.81 meters, and the sea depth ranged from 217 - 2089 meters. The average skipjack tuna were caught at the dept of 1389 meters. The highest catch in Fak-Fak waters was at position $3.350^{\circ} \mathrm{SL} ; 132.37^{\circ} \mathrm{EL}$ with a catch of 6.65 tons at SST $29.73^{\circ} \mathrm{C}$ and chlorophyll-a 0.30 $\mathrm{mg} / \mathrm{m} 3$.

In Transition Season I, the highest catch was in April with an average of $2236 \mathrm{~kg} / \mathrm{trip}$, the SST ranged from $29.68-30.24^{\circ} \mathrm{C}$ with an average of $29.88^{\circ} \mathrm{C}$ and a mode of $30.01^{\circ} \mathrm{C}$. Chlorophyll-a ranged from 0.11 to $4.14 \mathrm{mg} / \mathrm{m}^{3}$ with an average of $0.25 \mathrm{mg} / \mathrm{m}^{3}$ and mode of $0.19 \mathrm{mg} / \mathrm{m}^{3}$. Current velocity ranged from 0.07 to $0.50 \mathrm{~m} / \mathrm{s}$ with an average of $0.22 \mathrm{~m} / \mathrm{s}$. Wind speed ranged from 6.05 - 9.23 knots with an average of 7.6 knots. Sea waves ranged from 0.2 - 0.56 meters on average 0.35 meters with the depth of the sea from $154-2553$. The average skipjack were caught at a depth of 1262 meters. The highest catch in Fak-Fak waters was at position $3.47^{\circ} \mathrm{SL} ; 132.30^{\circ} \mathrm{EL}$ with a catch of 4.65 tons at SST $30.12^{\circ} \mathrm{C}$ and chlorophyll-a $0.212 \mathrm{mg} / \mathrm{m}^{3}$.

In the east monsoon, the highest catch occurred in August and September. The average number of catch in August was $2230 \mathrm{~kg} /$ trip. The SST ranged between 27.10 $29.15^{\circ} \mathrm{C}$ with an average of $28.01^{\circ} \mathrm{C}$ and mode $28.57^{\circ} \mathrm{C}$. Chlorophyll-a ranged from 0.24 to $0.70 \mathrm{mg} / \mathrm{m3}$ with an average of $0.37 \mathrm{mg} / \mathrm{m}^{3}$ and a mode of $0.13 \mathrm{mg} / \mathrm{m}^{3}$. Current speeds ranged from 0.07 to $0.66 \mathrm{~m} / \mathrm{s}$ with an average of $0.24 \mathrm{~m} / \mathrm{s}$. Wind Speed ranged from $10.90-$ 14.23 knots with an average of 12.87 Knots. Sea waves ranged from 0.85 to 1.65 meters, with an average of 1.29 meters. The sea depths ranged from 60 - 2094 meters. The average skipjack tuna is caught at a depth of 1270 meters. The highest catch in Fak-Fak waters is at 
$3,50^{\circ} \mathrm{SL} ; 132,13^{\circ} \mathrm{EL}$ with a total catch of 4.97 tons at SST $27.19^{\circ} \mathrm{C}$ and chlorophyll-a 0.36 $\mathrm{mg} / \mathrm{m}^{3}$. The average catch in September was $2513 \mathrm{~kg} /$ trip. The SST ranged between $27.82-$ $28.64{ }^{\circ} \mathrm{C}$ with an average of $28.41{ }^{\circ} \mathrm{C}$ and the mode was $28.62{ }^{\circ} \mathrm{C}$. Chlorophyll-a ranged from 0.14 to $0.31 \mathrm{mg} / \mathrm{m}^{3}$ with an average of $0.19 \mathrm{mg} / \mathrm{m}^{3}$ and a mode of $0.17 \mathrm{mg} / \mathrm{m3}$. Current speeds ranged from 0.06 to $0.43 \mathrm{~m} / \mathrm{s}$ with an average of $0.09 \mathrm{~m} / \mathrm{s}$. Wind Speed ranged from $10.67-13.63$ knots with an average of 12.29 Knots. Sea waves ranged between $0.81-1.48$ meters with an average of 1.15 meters. The sea depths ranged from $273-2044$ meters. The average skipjack tuna was caught at a depth of 1438 meters. The highest catch was in Seram Sea at $2.53^{\circ} \mathrm{SL} ; 130.27^{\circ}$ EL with a total catch of 6.23 tons at SST $28.60^{\circ}$ and C chlorophyll-a $0.21 \mathrm{mg} / \mathrm{m} 3$.

The highest catch of transitional season II was in October with an average of 2062 $\mathrm{kg} /$ trip. The SST ranged between $28.96-29.26{ }^{\circ} \mathrm{C}$ with an average of $29.10{ }^{\circ} \mathrm{C}$ and mode $29.24{ }^{\circ} \mathrm{C}$. Chlorophyll-a ranged from 0.15 to $0.33 \mathrm{mg} / \mathrm{m}^{3}$ with an average of $0.21 \mathrm{mg} / \mathrm{m}^{3}$ and mode $0.15 \mathrm{mg} / \mathrm{m}^{3}$. The current velocity ranged from 0.07 to $0.69 \mathrm{~m} / \mathrm{s}$ with an average of 0.23 $\mathrm{m} / \mathrm{s}$. Wind speed ranged from $6.67-8.7$ knots with an average of 7.4 knots. Sea waves ranged from $0.24-0.50$ meters, with an average of 0.34 meters. The sea depth ranged from $733-2646$ meters. The average skipjack tuna was caught at a depth of 1464 meters. The highest catch was in Seram Sea at $2,70^{\circ} \mathrm{SL} ; 130.65^{\circ} \mathrm{EL}$ with a catch of 6.16 tons at SST $29.02{ }^{\circ} \mathrm{C}$ and chlorophyll-a $0.24 \mathrm{mg} / \mathrm{m} 3$.

The results of image data analysis showed that the characteristics of oceanography in West Papua waters and its surroundings are classified as productive areas for the survival of skipjack tuna. According to Bambang (2004), Papua has potential tuna fish resources. Nontji (1993) stated that the optimum temperature for skipjack tuna is $16-30^{\circ} \mathrm{C}$. The results of the study by Simbolon et al. (2005) stated that the optimum temperature for skipjack catch ranged from $28-31{ }^{\circ} \mathrm{C}$. Based on Edmondri (1999), skipjack tuna had an optimum temperature range of $28-29^{\circ} \mathrm{C}$. This was because SST had a great influence on the distribution and migration of skipjack tuna (Zainuddin \& Jamal, 2009). If examined further, the value of chlorophyll-a concentration $>0.2 \mathrm{mg} / \mathrm{m} 3$ indicated that the existence of phytoplankton in the water is adequate to sustain the development of commercial fisheries (Gower, 1972).

According to Nugraheni (2015), one of the factors that cause a decrease in the catch is the state of the wind during fishing operations. Changes in weather and climate have influenced fisherman to change the fishing effort. Current is a very important parameter in the marine environment and directly or indirectly influences the marine environment and the biota within, including determining fish migration patterns. The currents in the sea are influenced by many factors, one of which is the monsoon (Wibisono, 2005).

The effort of catching skipjack tuna can be optimized by knowing the potential fishing grounds so that fisherman will generate benefit from the fishing operations.

Potential areas of skipjack tuna in West Papua waters and the surrounding areas have been mapped out based on the SST, chlorophyll-a, and the depth of the overlayed waters using a geographic information system. Jufri $(2014)$ stated that potential of skipjack tuna have close links with environmental parameters, especially the optimum SST at 29.9 $31.00 \mathrm{C}$, and optimum chlorophyll-a in the range of $0.12-0.22 \mathrm{mg} / \mathrm{m3}$.

Suitability of potential areas is divided into three categories: category 1 or non-potential areas (not suitable), category 2 or less potential area (less suitable), and category 3 very high potential areas (suitable). The criteria are arranged based the data skipjack tuna catch in 2018 using pole and line and the value of the SST oceanographic parameters, chlorophyll$a$, and depth of water taken based on the number of catches (Table 5).

The results of the mapping showed that not all regions have a suitable category (Figures 9 and 10). The distribution of potential fishing areas with the suitable category is found during the east monsoon and transitional seasons II (Figures 11 and 12).

West monsoon and transitional season I in West Papua waters and the surrounding areas are categorized as not suitable and less suitable. Both seasons have small spots, meaning they are not suitable for becoming potential areas at the position $0^{\circ} 30 " \mathrm{NL}-$ 
$2^{\circ} 20^{\prime \prime S L} ; 129^{\circ} 10^{\prime \prime}-131^{\circ} 00 \mathrm{EL}$. It includes the eastern part of Misool Island, Kafiau Island, Gag Island, and Waigeo Island (Figures 9 and 10).

Table 5 - Model of potential area suitability criteria of skipjack tuna catching

\begin{tabular}{|c|c|c|c|c|c|c|}
\hline \multirow{2}{*}{ No } & \multirow{2}{*}{ Parameter } & \multirow{2}{*}{ Unit } & \multicolumn{4}{|c|}{ Criteria of Conformity } \\
\cline { 4 - 7 } & & & Weight & Suitable (3) & Less suitable (2) & Not Suitable (1) \\
\hline 1 & Sea Surface Temperature & ${ }^{\circ} \mathrm{C}$ & 35 & $28-30.5$ & $27-28$ & $<27$ \\
\hline 2 & chlorophyll-a & $\mathrm{mg} / \mathrm{m}^{3}$ & 35 & $>=0.2$ & $0.1-0.19$ & $<0.1$ \\
\hline 3 & Waters depth & $\mathrm{m}$ & 30 & $>800$ & $41-800$ & $<40$ \\
\hline \multicolumn{2}{|c|}{ Total } & 100 & Score 3 & Score 2 & Score 1 \\
\hline
\end{tabular}

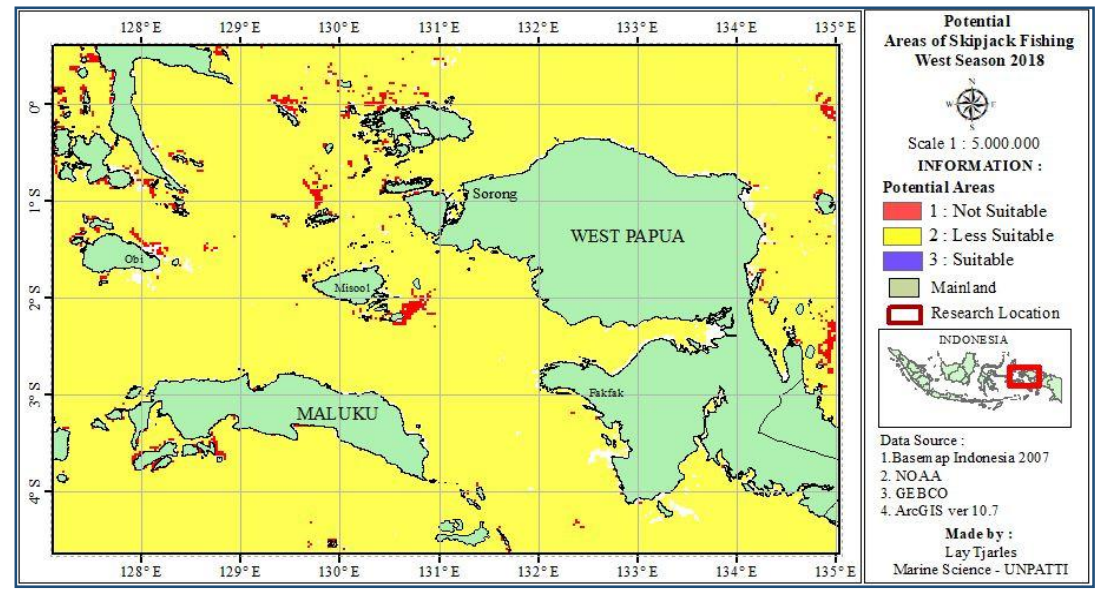

Figure 9 - Potential Areas to catch Skipjack Tuna West Monsoon

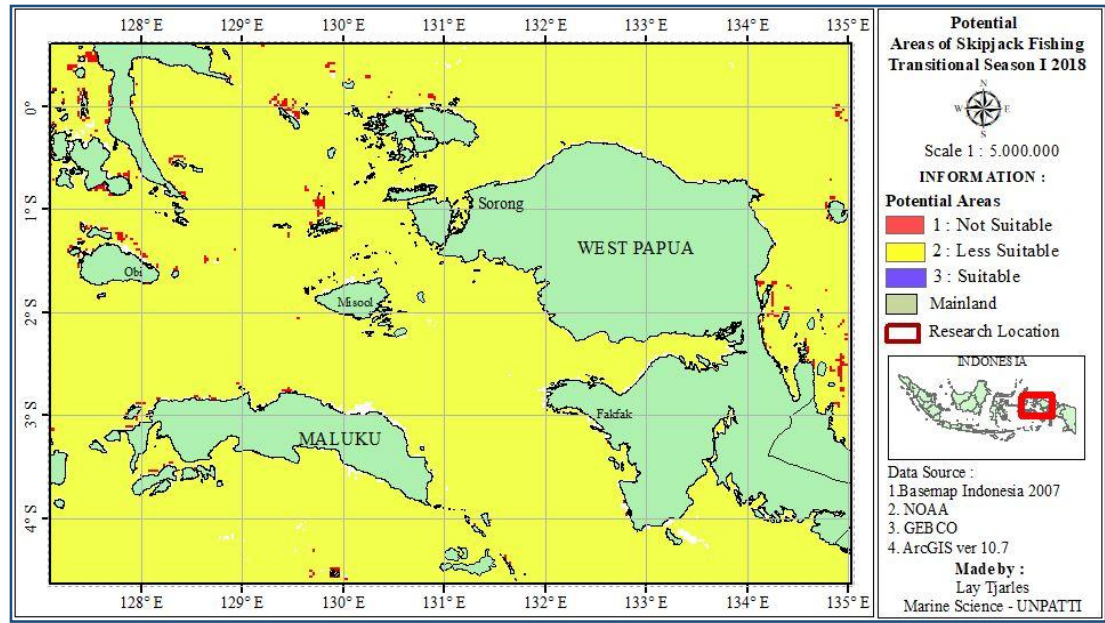

Figure 10 - Potential Areas to catch skipjack tuna Transitional Season I

In the east monsoon, the potential areas in West Papua waters are still dominant in the category of less suitable to fish skipjack tuna. The appropriate category as the skipjack fishing area tends towards the west at position $0^{\circ} 20^{\prime \prime N L}-03^{\circ} 10^{\prime \prime S L ; ~} 127^{\circ} 00^{\prime \prime}-131^{\circ} 00^{\prime \prime E L}$, including the Halmahera Sea and part of the Seram Sea (Figure 11). Transitional Season II is a good skipjack fishing area. Based on the results of prediction mapping, the potential areas are categorized as less suitable. The suitable category is there in all research areas including Fakfak waters, Seram sea, Halmahera sea, Manokwari waters, and southern Maluku islands (Figure 12). 


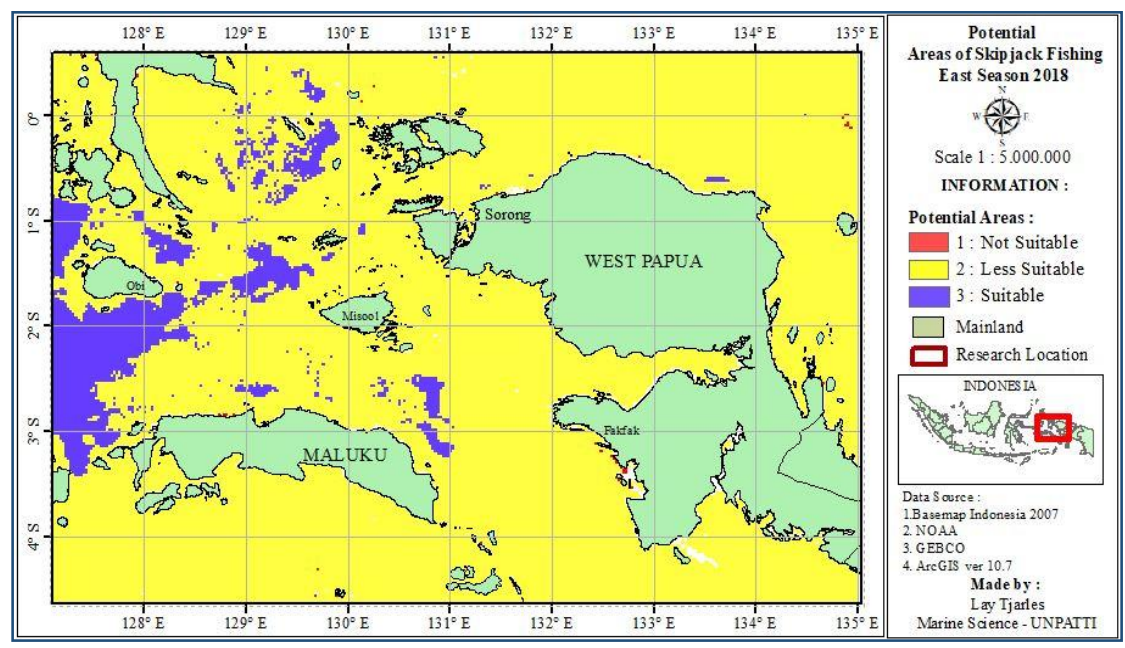

Figure 11 - Potential Areas of skipjack tuna catch East Monsoon

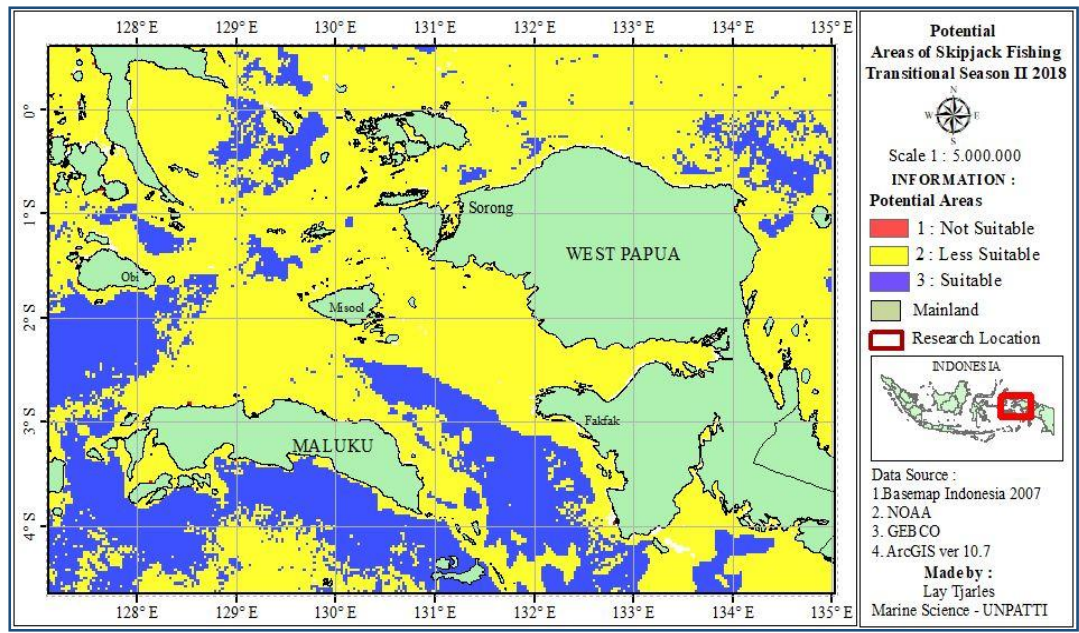

Figure 12 - Potential Areas of skipjack tuna catch Transitional Season II

\section{CONCLUSION AND SUGGESTION}

The results of the parameter characteristics of oceanography showed that West Papua waters have good potential marine resources for the survival of pelagic fish, especially skipjack fish. Skipjack fishing catch can be done throughout the year with a fishing ground where the most catch in Seram Sea and Fakfak waters. Predictions of potential areas show that the East Monsoon and Transitional seasons II are very suitable for skipjack fishing operations.

To determine the potential areas of skipjack catch with a better level of accuracy, further research is recommended using daily and weekly multi-sensor satellite image data.

\section{REFERENCES}

1. Birowo, S. 1980. Peta Oseanografi hasil pelayaran Selama Pelita II (1974 - 1977).Bab 1.Hidro Oseanografi Perairan Indonesia and sekitarnya 1980.Buku 3.(A.Soegiato, S.Birowo and Soekarno eds), LON-LIPI:10-14.

2. Chen TB, Zheng YM, Lei M, Huang ZC, Wu HT, Chen H, Fan KK, Yu K, Wu X, Tian QZ. 2005. Assessment of Heavy Metal Pollution in Surface Soils of Urban Parks in Beijing, China.Chemosphere 60:542 - 551 . 
3. Direktorat Perencanaan Ruang Laut, 2017.Tata Cara penyusunan peta rencana zonasi wilayah pesisir and pulau-pulau kecil.DJPRL.KKP.

4. Jufry A. 2014.Karakteristik daerah penangkapan ikan Cakalang pada musim barat di perairan Teluk Bone.Jurnal IPTEKS PSP, vol.1 (1) April 2014:1-10.ISSN:2355 - 729X.

5. Hasriyanti, Erman S, Maddatuang.2015.Analisis karakteristik kedalaman perairan, arus and gelombang di pulau Dutungan Kabupaten Barru.Jurnal Scientific Pinisi Vol.1 No.1 Oktober 2015.

6. Kelautan Perikanan Dalam Angka.2018.Kementerian Kelautan and Perikanan.https://kkp.go.id/setjen/satudata/artikel/9669-kelautan-dan-perikanan-dalamangka-2018-telah-terbit

7. Munirah, T. 2018. Sumber daya Ikan cakalang.Ideas publishing.IP.084.12.2018.ISBN 978-602-5878-59-6

8. Nugraheni P, 2015. Dampak Perubahan Cuaca Terhadap Produktivitas and Pendapatan Nelayan di Pelabuhan Perikanan Pantai(PPP) Asemdoyong, Pemalang

9. Nontji A., 1993. Laut Nusantara.Jakarta:Djambatan

10. Robinson, I.S, 1985. Satellite Oceanography an Introduction for Oceanographer and Remote Sensing Scientists, Ellis Horwood.England.59 pages

11. Simbolon D, Halim A. 2005. Suhu permukaan laut and kaitannya dengan hasil tangkapan ikan cakalang and madidihang di Perairan Sumatera Barat.Buletin Pemanfaatan Sumberdaya Perairan. Institut Pertanian Bogor.Bogor

12. Waas H.J.D.2004. Analisis Daerah Potensial Penangkapan Cakalang (Katsuwonus Pelamis) and Madidihang (Thunnus albacores) di perairan utara Papua, Pasifik Barat.Tesis.Institut Pertanian Bogor.

13. Wibisono, M.S. 2005. Pengantar Ilmu Kelautan.PT Grasindo anggota IKAPI.Jakarta. 